\title{
Correction to: The Potato of the Future: Opportunities and Challenges in Sustainable Agri-food Systems
}

\author{
André Devaux ${ }^{1}(1) \cdot$ Jean-Pierre Goffart ${ }^{2}(1) \cdot$ Peter Kromann $^{3}(1)$.

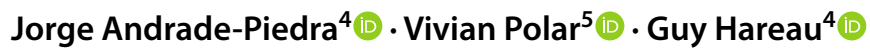

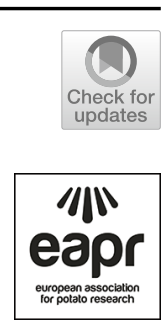

Published online: 29 October 2021

(c) The Author(s) 2021

\section{Correction to: Potato Research https://doi.org/10.1007/s11540-021-09501-4}

The article "The Potato of the Future: Opportunities and Challenges in Sustainable Agri-food Systems", written by André Devaux, Jean-Pierre Goffart, Peter Kromann, Jorge Andrade-Piedra, Vivian Polar, and Guy Hareau, was originally published electronically on the publisher's internet portal on 24 July 2021 without open access. With the author(s)' decision to opt for Open Choice the copyright of the article changed on 23 September 2021 to (C) The Author(s) 2021 and the article is forthwith distributed under a Creative Commons Attribution 4.0 International License, which permits use, sharing, adaptation, distribution and reproduction in any medium or format, as long as you give appropriate credit to the original author(s) and the source, provide a link to the Creative Commons licence, and indicate if changes were made. The images or other third party material in this article are included in the article's Creative Commons licence, unless indicated otherwise in a credit line to the material. If material is not included in the article's Creative Commons licence and your intended use is not permitted by statutory regulation or exceeds the permitted use, you will need to obtain permission directly from the copyright holder. To view a copy of this licence, visit http://creativecommons.org/licenses/by/4.0.

The original article can be found online at https://doi.org/10.1007/s11540-021-09501-4.

André Devaux

andrej.devaux@gmail.com

1 International Potato Center (CIP), Louvain-la-Neuve, Belgium

2 Walloon Agriculture Research Center, CRA-W, Gembloux, Belgium

3 Field Crops, Wageningen Plant Research, Wageningen University \& Research, Lelystad, The Netherlands

4 International Potato Center (CIP), CGIAR Research Program on Roots Tubers and Bananas, Lima, Peru

5 CGIAR Research Program on Roots, Tubers and Bananas (RTB), CIP, Lima, Peru 


\section{The original article has been corrected.}

Open Access This article is licensed under a Creative Commons Attribution 4.0 International License, which permits use, sharing, adaptation, distribution and reproduction in any medium or format, as long as you give appropriate credit to the original author(s) and the source, provide a link to the Creative Commons licence, and indicate if changes were made. The images or other third party material in this article are included in the article's Creative Commons licence, unless indicated otherwise in a credit line to the material. If material is not included in the article's Creative Commons licence and your intended use is not permitted by statutory regulation or exceeds the permitted use, you will need to obtain permission directly from the copyright holder. To view a copy of this licence, visit http://creativecommons.org/ licenses/by/4.0/.

Publisher's Note Springer Nature remains neutral with regard to jurisdictional claims in published maps and institutional affiliations. 